\title{
Alveolar echinococcosis presenting with simultaneous cerebral and spinal involvement
}
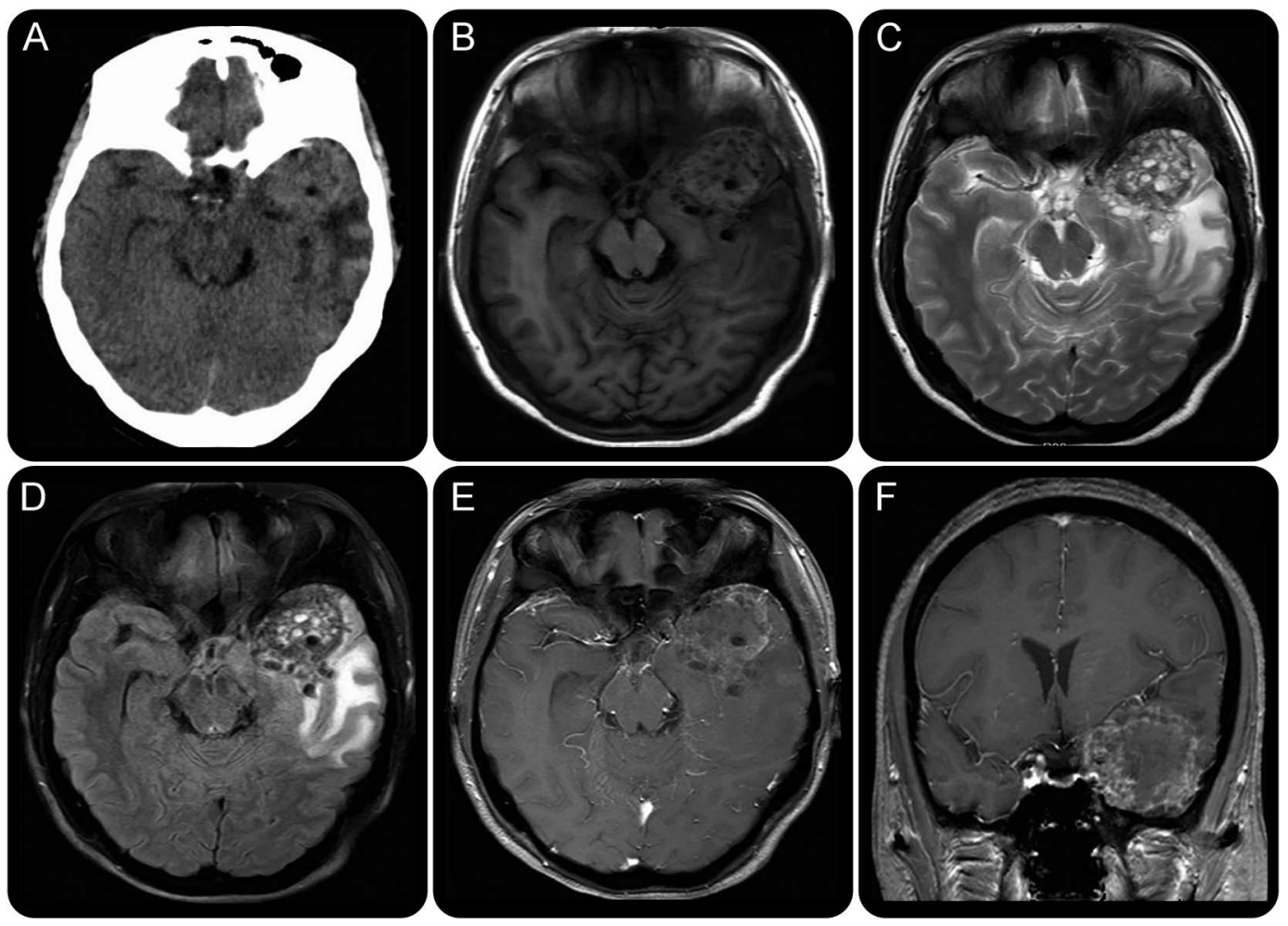

(A) Axial CT scan reveals a heterogeneous solid mass containing multiple hypodense cystic areas and shows extensive peripheral edema. (B) Axial T1-weighted, (C) axial T2-weighted, and (D) fluid-attenuated inversion recovery sequence MRI show an inhomogeneous spherical mass with multiple central cystic-necrotic areas. (E) Axial enhanced T1-weighted and (F) coronal enhanced T1-weighted MRI show irregular peripheral enhancement of the lesion.

A 37-year-old Tibetan shepherdess presented with headache and weakness of the lower limbs for 10 months. Examination disclosed a positive straight-leg-raising test. Neuroimaging showed a heterogeneous mass in the left temporal lobe (figure 1) and an intradural mass in the lumbosacral canal with L4 vertebral body destruction (figure 2). Chest and abdominal CT scans were negative. Two operations yielded a tissue diagnosis of alveolar echinococcosis and postoperative albendazole therapy was started. Simultaneous involvement of brain and the spinal cord in primary extrahepatic alveolar echinococcosis is rare. Early diagnosis and radical surgery followed by continuous benzimidazole treatment are crucial. ${ }^{1}$

Jian Cheng, MD, ${ }^{*}$ Jinli Meng, MD, ${ }^{*}$ Wanlin He, MD, Xuhui Hui, MD

*These authors contributed equally to this work.

From the Department of Neurosurgery (J.C., X.-H.H.), West China Hospital, Sichuan University; and Department of Radiology (J.-L.M., W.-L.H.), Hospital of Chengdu, Office of People's Government of Tibetan Autonomous Region (Hospital C.T.), Chengdu, P.R. China. Author contributions: Jian Cheng: study design, data collection and analysis, drafting the manuscript, revising the manuscript. Jinli Meng: data collection, drafting the manuscript, revising the manuscript. Wanlin He: acquisition of data, analysis and interpretation of data, study supervision. Xuhui Hui: study concept and design, study supervision, revising the manuscript for important intellectual content.

Study funding: No targeted funding reported. 

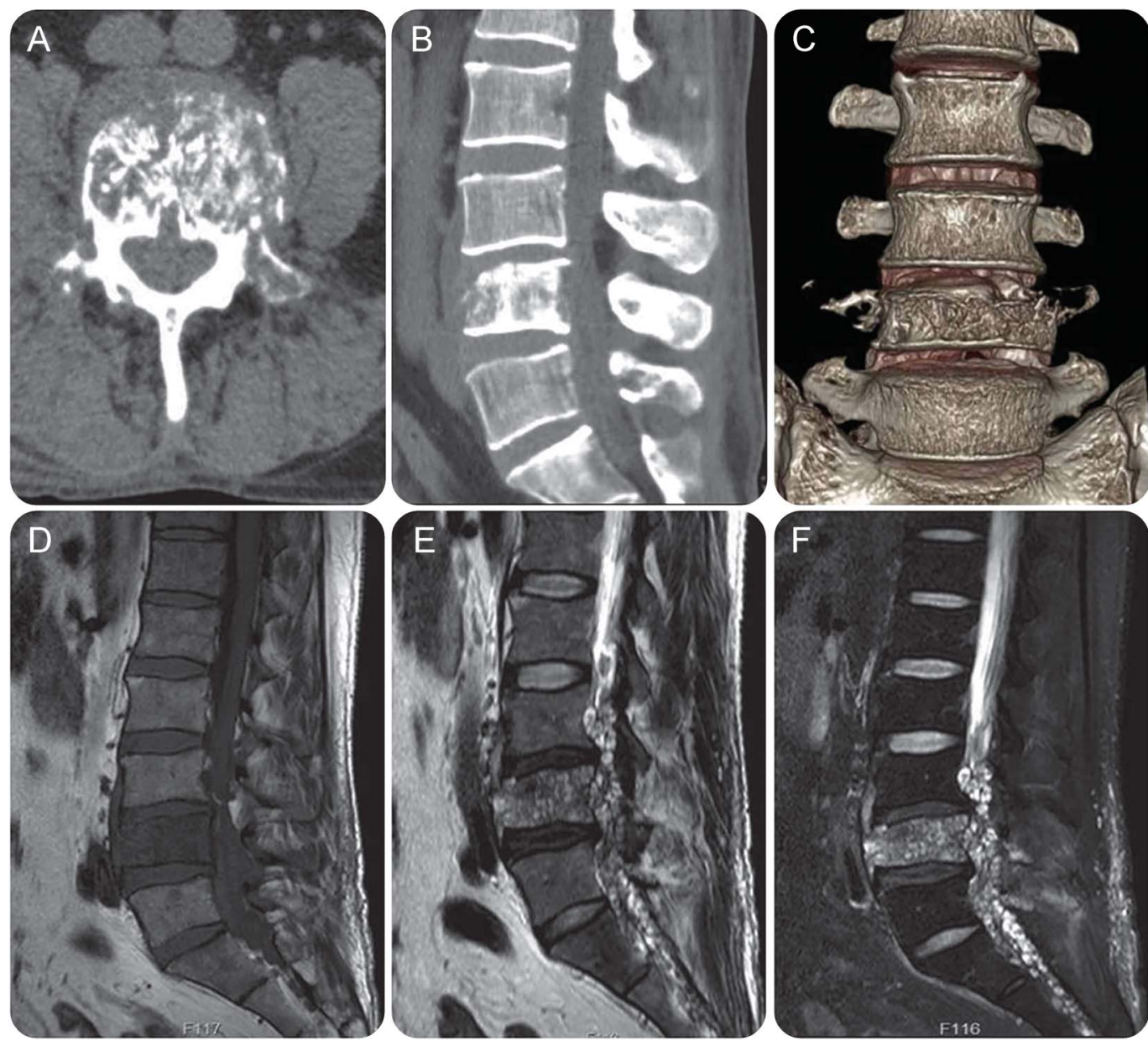

(A) Axial, (B) sagittal, and (C) 3D CT images of the lumbar spine reveal extensive vertebral body destruction of L4. (D) T1weighted image, (E) T2-weighted image, and (F) T2-weighted short tau inversion recovery image of the lumbar spine in sagittal orientation show a heterogeneous invasive mass at L3-S2 with L4 vertebral body destruction.

Disclosure: The authors report no disclosures relevant to the manuscript. Go to Neurology.org for full disclosures.

Correspondence to Dr. Hui:892910276@qq.com

1. Brunetti E, Kern P, Vuitton DA. Expert consensus for the diagnosis and treatment of cystic and alveolar echinococcosis in humans. Acta Trop 2010;114:1-16.

\section{Get Connected. Stay Connected.}

Connect with the American Academy of Neurology's popular social media channels to stay up-todate on the latest news and breakthroughs in neurology, and network with peers and neurology thought leaders. Visit AAN.com/Connect. 


\title{
Neurology
}

\author{
Alveolar echinococcosis presenting with simultaneous cerebral and spinal involvement \\ Jian Cheng, Jinli Meng, Wanlin He, et al. \\ Neurology 2017;88;2153-2154 \\ DOI 10.1212/WNL.0000000000003991
}

This information is current as of May 29, 2017

\begin{tabular}{|c|c|}
\hline $\begin{array}{l}\text { Updated Information \& } \\
\text { Services }\end{array}$ & $\begin{array}{l}\text { including high resolution figures, can be found at: } \\
\text { http://n.neurology.org/content/88/22/2153.full }\end{array}$ \\
\hline References & $\begin{array}{l}\text { This article cites } 1 \text { articles, } 0 \text { of which you can access for free at: } \\
\text { http://n.neurology.org/content/88/22/2153. full\#ref-list-1 }\end{array}$ \\
\hline Subspecialty Collections & $\begin{array}{l}\text { This article, along with others on similar topics, appears in the } \\
\text { following collection(s): } \\
\text { CT } \\
\text { http://n.neurology.org/cgi/collection/ct } \\
\text { MRI } \\
\text { http://n.neurology.org/cgi/collection/mri } \\
\text { Parasitic infections } \\
\text { http://n.neurology.org/cgi/collection/parasitic_infections } \\
\text { Spinal cord infection } \\
\text { http://n.neurology.org/cgi/collection/spinal_cord_infection }\end{array}$ \\
\hline Permissions \& Licensing & $\begin{array}{l}\text { Information about reproducing this article in parts (figures,tables) or in } \\
\text { its entirety can be found online at: } \\
\text { http://www.neurology.org/about/about_the_journal\#permissions }\end{array}$ \\
\hline Reprints & $\begin{array}{l}\text { Information about ordering reprints can be found online: } \\
\text { http://n.neurology.org/subscribers/advertise }\end{array}$ \\
\hline
\end{tabular}

Neurology ${ }^{\circledR}$ is the official journal of the American Academy of Neurology. Published continuously since 1951, it is now a weekly with 48 issues per year. Copyright @ 2017 American Academy of Neurology. All rights reserved. Print ISSN: 0028-3878. Online ISSN: 1526-632X.

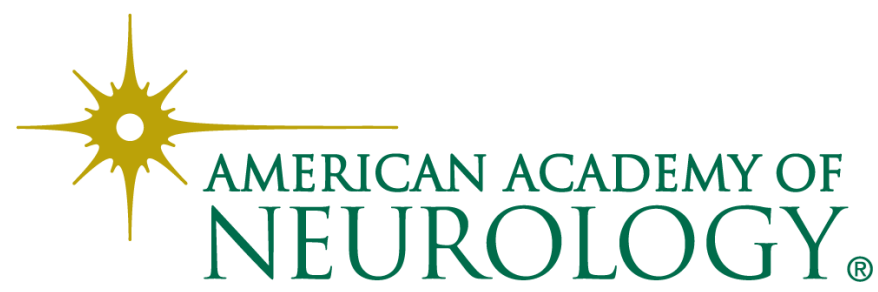

